\title{
INFESTATION STUDY OF LIVONECA REDMANII (ISOPODA, CYMOTHOIDAE) ON SOLEA SOLEA IN LAKE QARUN, EGYPT
}

By

HASSAN M. M. KHALAF-ALLAH ${ }^{*}$ AND OSAMA E. A. YOUSEF

Marine Biology Branch, Zoology Department, Faculty of Science, Al-Azhar

University, Cairo, Egypt ( ${ }^{*}$ Correspondence:h_mashhout@yahoo.com)

\section{Abstract}

The study dealt with the infestation of Livoneca redmanii (Isopoda, Cymothoidae) on Solea solea in Lake Qarun, Egypt. 487 specimens of $S$. solea were examined to extract 99 crustacean parasites. Fish specimens were collected monthly from Eastern and Western regions of Lake Qarun, during the period from January to December, 2016.

The results showed that $S$. solea was infested by L. redmanii. The highest infestation recorded was in June b, $38.64 \%$ and the lowest one $(10.34 \%)$ in October. The infested fish S. solea were mostly females. The highest male infestation was during March (18.37\%) and the lowest in April (2.04\%). The highest female infestation was during July (22\%) and the lowest in August and October (2\%). The highest infestation (37.38\%) was in mid length group $14 \mathrm{~cm}$ and the lowest $(1.01 \%)$ was in large fish at length group $19 \mathrm{~cm}$. The highest infestation $(43.44 \%)$ was in weight group $30 \mathrm{gm}$ and the lowest one (3.07\%) was in largest and smallest fishes at weight group $10 \& 70 \mathrm{gm}$. The ecto-parasitic Isopods, $L$. redmanii infest gills, ventral side, dorsal side, mouth, head and tail sites on the integument of $S$. solea. The bilateral and/or unilateral infestation per fish was in gills region $(73.7 \%)$. The main clinical signs in infested S. solea were respiratory distress as surface swimming with opened mouth and gill cover. Also, they showed sluggish movement, emaciation, excessive amounts of mucous covering the body surface. Post-mortum examination showed lesions of focal erosion in skin and gills.

Based on the parasitic treatment trails with salinity, the most suitable solution to make control on the parasite blooming was increasing the fresh water flow to adjust the parasite activity and to minimize the optimum condition of blooming.

Key words: Lake Qarun, Infestation, Livoneca redmanii, Solea solea,

\section{Introduction}

Isopods recorded to parasites many species of commercially important fishes worldwide causing significant economic losses to fisheries (Rameshkumar et al, 2013), where the incidence and intensity of parasitic isopods exhibit a considerable variation (Grutter, 2003; Cuyas et al, 2004).

Isopoda are prospective the leading group of the fish crustacean parasites (Kabata, 1984). They are actually economically significant parasites as they have deleterious effects on cultured fish, such as stunted growth, anemia, and mortalities of fries and fingerlings (Ravi and Rajkumar, 2007; Ravichandran et al, 2011). The aquatic environment with its water quality is considered the main factor for the state of health in both cultured and wild fish (Saeed and Shaker, 2008). Salinity is importantly affecting Lake Qarun biota (Khalaf-Allah, 2014).

Lake Qarun constitutes a very important sector in the Egyptian fisheries, for both sig- nificant total catch and a large number of economically important species. Mugil cephalus, M. Capito, M. saliens, Liza aurata, Solea solea and Tilapia zillii were the dominant species in the lake waters. Dicentrarchus labrax, Sparus aurata, Anguilla anguilla and Oreochromis niloticus are rarely found in commercial catch. The fries of mullets, seabass and seabream were mechanical transported from El-Max Station in Mediterranean Sea to this lake Azab et al. (2015). The introducing of fish fry from the Mediterranean Sea and other sources into the lake added other non-commercial species (Khalaf-Allah, 2014). Azab et al. (2015) found that small fish were not collected during November in all sites. The disappearance of small fish in Lake Qarun may be due to the heavily abundance of crustacean parasites, which come from the Mediterranean Sea with fish fry caused severe damage to the lake fish stock. The problem in Lake Qarun that prospected in isopod infestation among 
fishes was noticed by fish loss and marketing problems.

The present study aimed to provide more information about prevalence, infection site, clinical signs and trials to treat Livoneca redmanii (Isopoda: Cymothoidae) infesting Solea solea at Lake Qarun, Egypt.

\section{Material and Methods}

The study area: this work included the South coast of Lake Qarun, Egypt. It is located about $80 \mathrm{Km}$ southwest of Cairo between $30^{\circ} .41778^{`} \& 30^{\circ} .8275^{`} \mathrm{E}$ and latitudes $29^{\circ} .44194^{\circ} \& 29^{\circ} .51111^{\circ} \mathrm{N}$ in the lowest part of El-Fayoum depression (Fig. 1).

A total of 487 of Solea solea formed the materials for the present study. Fish specimens were collected monthly from two stations of Lake Qarun, during the period from January to December, 2016. Gill net and encircling net were the main fishing method used to collect the fish. Wherever possible fish were examined fresh or preserved in $10 \%$ formalin solution for latter examination. In the laboratory, fish were taxonomically identified (Khalaf-Allah, 2014). Total and standard lengths were measured to the nearest millimeter and recorded. Fish were also weighted to the nearest 0.1 gram and then the following studies were carried out. Crustacean isopod parasite, Livoneca redmanii (Fig. 2) were collected from S. solea and taxonomically identified (Brusca, 1981).

Infested fish were carefully examined and parasites were removed from different Isites as gills and skin, counted per fish and photographed.
Clinical examination: Fishes were examined for any clinical picture caused by the parasites (Woo, 2006). Infested site was carefully examined to identify its target organ.

Experimental parasite treatment: A total of 30 free male specimens of crustacean isopod parasite, Livoneca redmanii with a good condition were obtained from Lake Qarun in July, 2017. Parasites were transported to laboratory of marine invertebrates at Zoology Department, Faculty of Science, Al-Azhar University in a large plastic bag containing about 20L of water and a lot of oxygen. In the laboratory, parasites were acclimatized for a day in well aerated glass tank $(100 x 50 x$ $50 \mathrm{~cm}$ ) before starting the experiment.

Five groups of 5 parasites each were isolated in plastic tank $1 \mathrm{~L}$, well aerated and filled with dechlorinated water $(\mathrm{pH}=7.2 \pm 0.50)$. A graduated salinity concentration was added to the tanks. Exposure was continued for 5 days with concentrations of fresh water, 10, 20, 30, 40g/L. Daily observations for treated groups were done to investigate the dead and life parasites. The dead parasites were removed immediately and recorded.

\section{Results}

Monthly prevalence of Livoneca redmanii on S. solea was $99 / 487(20.33 \%)$. Of them $97(97.98 \%)$ were infested by one parasite, while other two were double infested. Double infestation was in March and June. Infestation varied between $(38.64 \%)$ in June \& $(10.34 \%)$ in October. Others were $(12.5 \%)$ in August and (32.0\%) in November (Tab. 1; Fig. 3).

Table 1: Monthly prevalence infestation rate of Livoneca redmanii on Solea solea at Lake Qarun, year 2016
\begin{tabular}{|c|c|c|c|c|c|}
\hline \multirow{2}{*}{ Months } & \multicolumn{2}{|c|}{ Number of fish } & Infestation type & \multirow{2}{*}{$\begin{array}{c}\text { Infestation } \\
\text { percentage }\end{array}$} \\
\cline { 2 - 6 } & Examined & Infested & Single & Double & 15.79 \\
\hline January & 76 & 12 & 12 & & 13.75 \\
\hline February & 43 & 6 & 6 & & 16.90 \\
\hline March & 71 & 12 & 11 & 1 & 15.79 \\
\hline April & 19 & 3 & 3 & & 23.33 \\
\hline May & 30 & 7 & 7 & & 38.64 \\
\hline June & 44 & 17 & 16 & 1 & 23.53 \\
\hline July & 68 & 16 & 16 & & 12.50 \\
\hline August & 24 & 3 & 3 & & 17.24 \\
\hline September & 29 & 5 & 5 & & 10.34 \\
\hline October & 29 & 3 & 3 & & 32.00 \\
\hline November & 25 & 8 & 8 & & 24.14 \\
\hline December & 29 & 7 & 7 & & 20.33 \\
\hline Total & 487 & 99 & 97 & 2 & \\
\hline
\end{tabular}




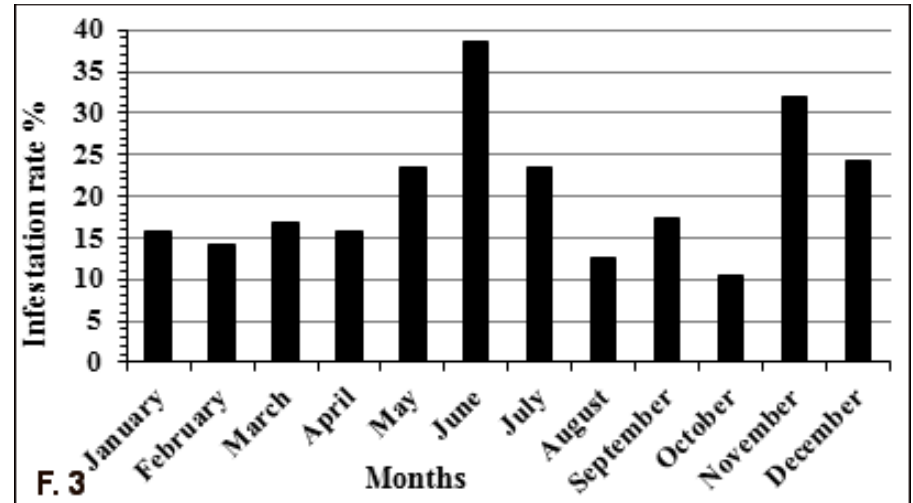

Fig. 3: Monthly prevalence infestation percentages of Livoneca redmanii on Solea solea at Lake Qarun, year 2016

Prevalence of L. redmanii on S. solea: Infested males were 49(49.49\%) with pick in March $(18.37 \%)$ and lowest in April $(2.04 \%)$. Others were between $(4.08 \%)$ in August to November and (16.33\%) in Janu- ary to June. Infested females were 50 $(50.51 \%)$, very small rate in October $(2.0 \%)$ to January $(8.0 \%)$. Picks were in June, July \& November $(18 \%, 22 \% \& 12 \%)$ respectively (Tab. 2; Fig. 4).

Table 2: Monthly infestation\% of L. redmanii on male and female Solea solea at Lake Qarun, year 2016

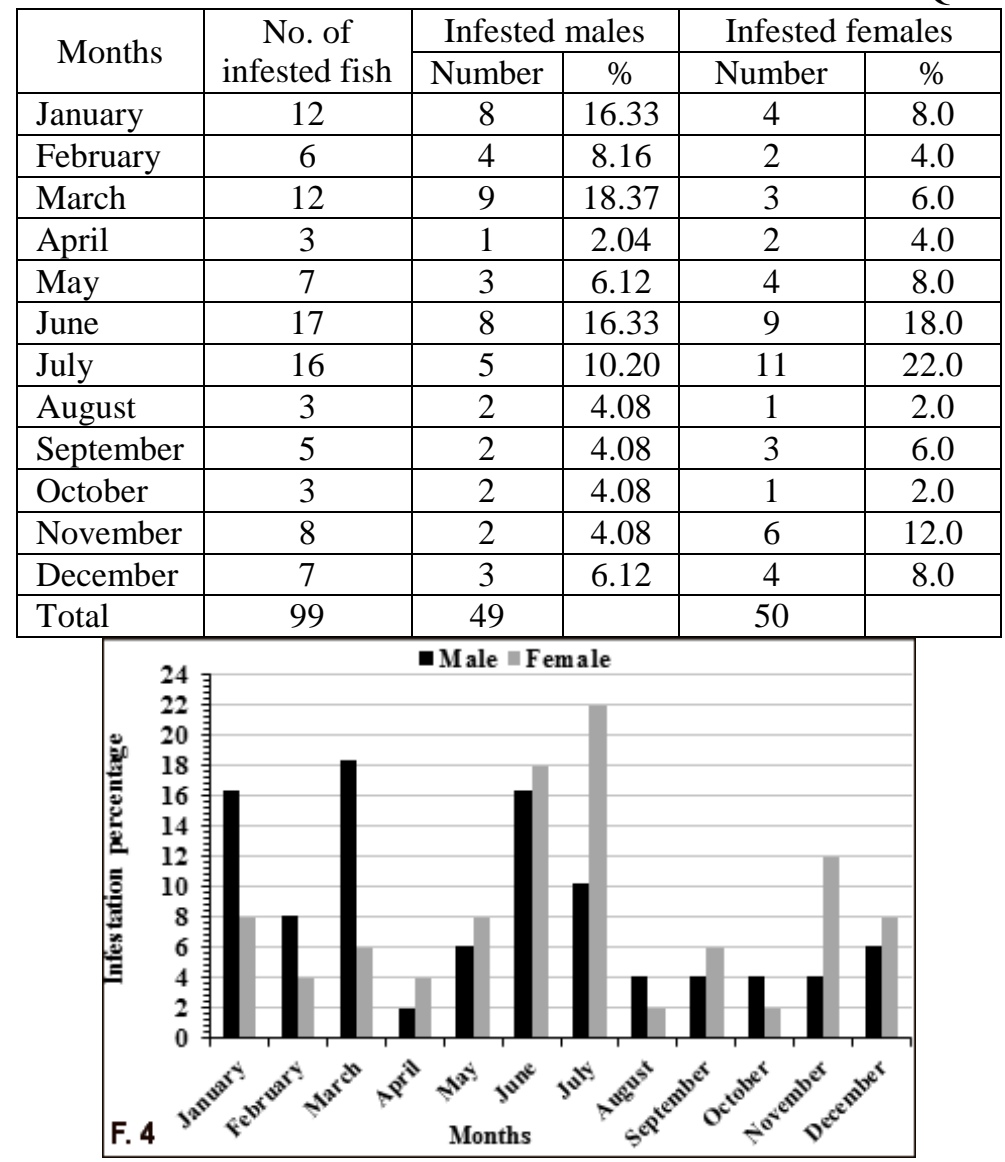

Fig. 4: Monthly prevalence infestation percentage of Livoneca redmanii on males and females Solea solea at Lake Qarun, year 2016

Prevalence of L. redmanii, on S. solea as to length and weight: Of 99 infested fish, 75 fish $(75.76 \%)$ were of middle length ranged from $12-15 \mathrm{~cm}, 19(19.19 \%)$ of size over $15 \mathrm{~cm}$. The highest infestation was $(37.38 \%)$ on fish length $14 \mathrm{~cm}$ and the lowest one $(1.01$ $\%$ ) on fish length $19 \mathrm{~cm}$. Infestation in others lengths fluctuated between $(3.03 \%)$ on fish length $17 \mathrm{~cm}$ and $(15.15 \%)$ on length $13 \mathrm{~cm}$. None was infested with parasite length more 
than $19 \mathrm{~cm}$ (Fig. 5). There were $81(81.82 \%)$ infested fish with weight ranged between 20 $\& 40 \mathrm{gm}$, but infested fishes over $50 \mathrm{gm}$ was $7(7.07 \%)$. Highest infestation (43.44\%) was on fish with weight $30 \mathrm{gm}$ and the lowest one was on fish with weight bet- ween $10 \&$ $70 \mathrm{gm}(3.07 \%)$. Infestation on other weights was $(4.04 \%)$ on weight $60 \mathrm{gm}$ and $(21.21 \%)$ on weight $20 \mathrm{gm}$. None was infested fish over weight of 70gm (Tab. 3; Fig. 6).

Table 3: Infestation \% of L. redmanii on S. solea as to length (cm) and weight (g) at Lake Qarun, year 2016

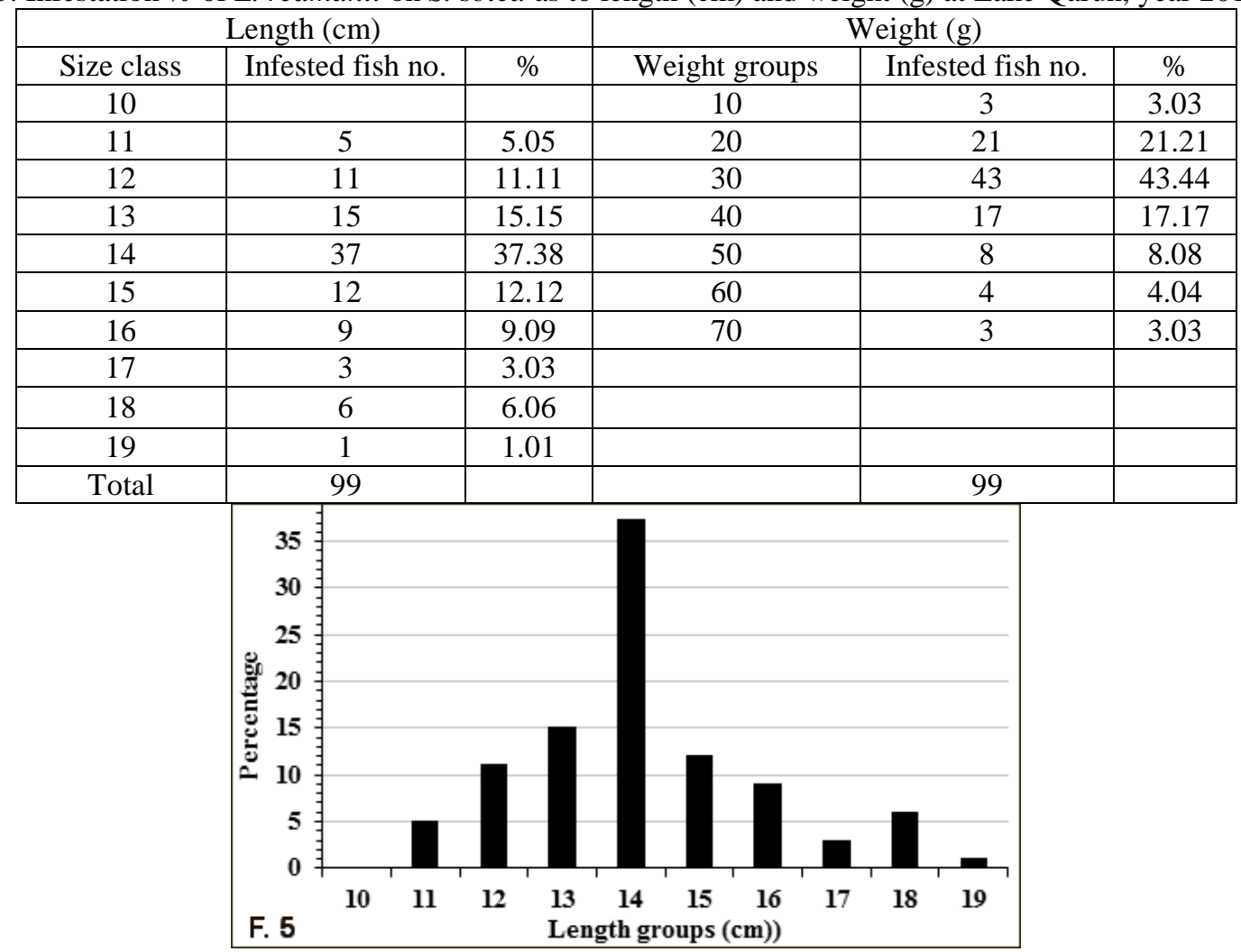

Fig. 5: Infestation percentage of Livoneca redmanni on Solea solea in relation to their length groups (cm) at Lake Qarun, year 2016

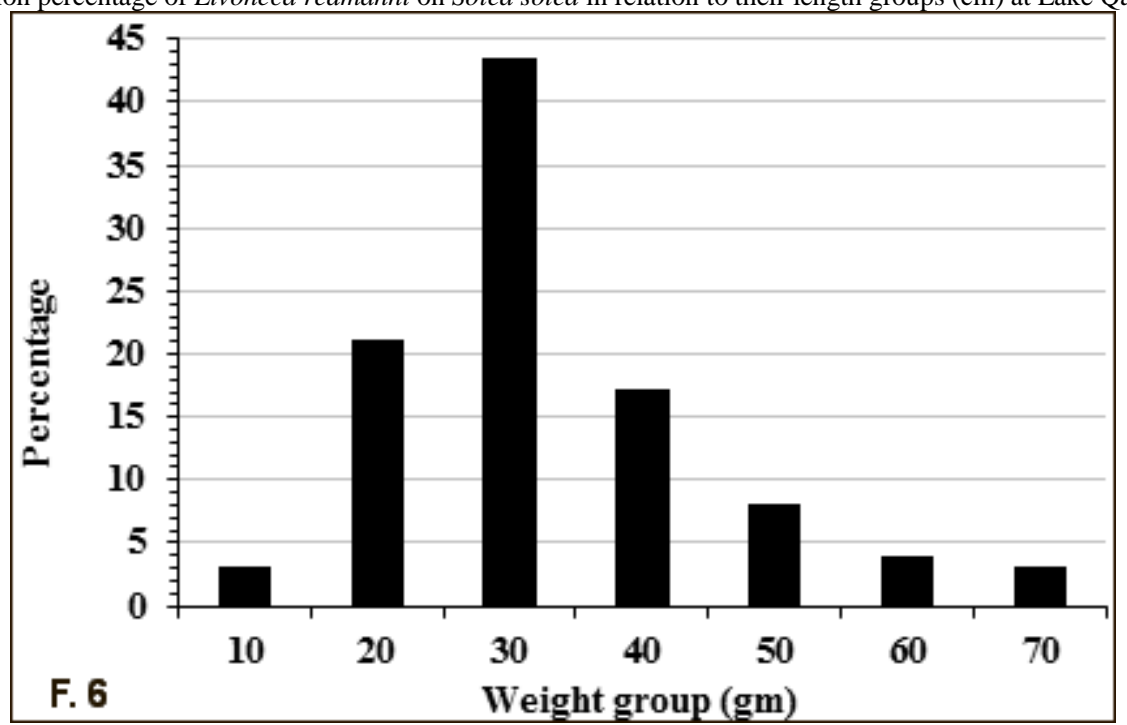

Fig. 6: Infestation percentage of Livoneca redmanni on Solea solea in relation to their weight groups (g) at Lake Qarun, year 2016

Sites of infection: S. solea infested ones were mostly females. Ecto-parasitic Isopods, Livoneca redmanii infest gills, ventral side, dorsal side, mouth, head and tail sites on the integument. They were attached with their appendages deeply embedded in fish muscles and anchored themselves by their hooks in the terminal appendages (Figs. $7 \& 8$ ). 
Infestation sites: L. redmanii was in gills 73 specimens $(73.7 \%), 11(11.1 \%)$ at dorsal side, $6(6.06 \%)$ at ventral side, $4(4.04 \%)$ at mouth, $3(3.03 \%)$ at head and $2(2.02 \%)$ at tail region (Fig. 9).

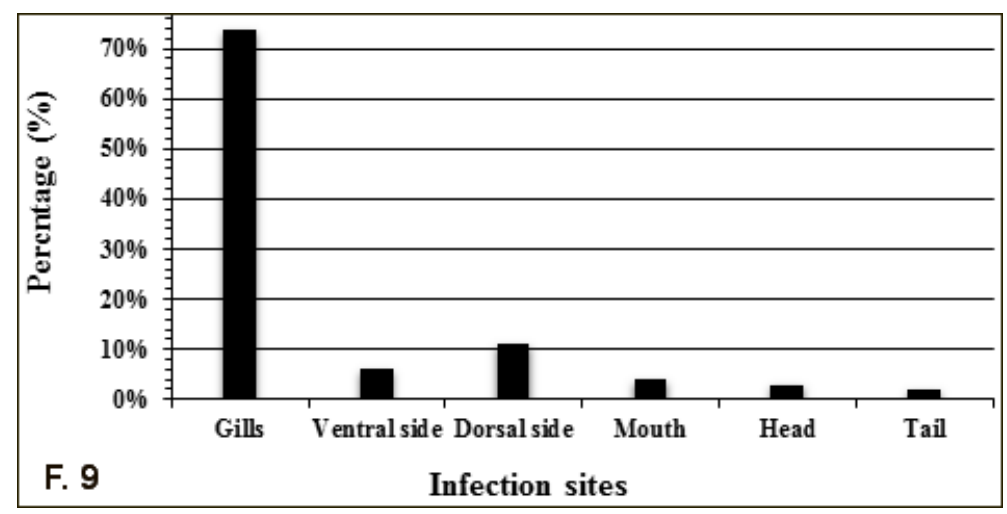

Fig 9: Sites of infestation (\%) by Livoneca redmanii among S. solea at Lake Qarun, year 2016

Clinical signs and post mortum lesions of infested Solea solea with Livoneca redman$i i$ : The main clinical signs in naturally infested $S$. solea appeared in respiratory distress manifested by surface swimming with opened mouth and gill cover.

Also, some fishes showed sluggish movement, emaciation, excessive amounts of mucous covering the body surface and bulging of the operculum due to the presence of the large sized isopod parasite (Figs. 10 \& 11).

The investigation of $S$. solea revealed that either single bilateral and/or double unilateral infestation of their gills per host fish and protrusion of posterior part of the parasite protruded outside the body of the fish (Fig. 12). Examination of post mortem lesions of infested S. solea by L. redmanii showed that the appearance of focal erosion in skin and gills (Fig., 13).

Parasites treatment: Treatment was applied by a serial gradient of salinity: fresh water, $10,20,30 \& 40 \mathrm{gm} / \mathrm{L}$. In fresh water aquarium, all L. redmanii died after 30 minutes post treatment. In brackish water aquarium (10 ppt.), all L. redmanii survived on the first day, on the next day few died one by one but on the third day still $60 \%$ survived. In brackish water aquarium (20 ppt.) all parasites survived up to the $4^{\text {th }}$ day, but at the end of experiment only $80 \%$ survival. The same results were achieved with the last two salinity treatment $(30 \& 40 \mathrm{gm} / \mathrm{L})$. Thus, the most suitable solution to control the parasite blooming was by increasing the fresh water flow in target body of water to stop parasite activity minimizing the optimum condition of blooming.

Table 4: Dead Livoneca redmanii treated by different concentrations of salinity, 5 days after exposures

\begin{tabular}{|c|c|c|c|c|c|c|c|c|c|c|}
\hline \multirow{2}{*}{$\begin{array}{l}\text { Treatment } \\
\text { water }\end{array}$} & \multirow{2}{*}{$\begin{array}{l}\text { Salinity conc. } \\
\text { ppt. }\end{array}$} & \multirow{2}{*}{$\begin{array}{c}\text { Parasites } \\
\text { No. }\end{array}$} & \multicolumn{5}{|c|}{ Time of exposure (days) } & \multicolumn{2}{|c|}{ Treatment } & \multirow[t]{2}{*}{ Survival \% } \\
\hline & & & 1 & 2 & 3 & 4 & 5 & Dead & Live & \\
\hline Fresh water & 1 & 5 & 5 & & & & & 5 & 0 & 0 \\
\hline \multirow{2}{*}{ Brackish water } & 10 & 5 & & 1 & 1 & & & 2 & 3 & 60 \\
\hline & 20 & 5 & & & & & 1 & 1 & 4 & 80 \\
\hline Salt water & 30 & 5 & & & & & 1 & 1 & 4 & 80 \\
\hline High Salt water & 40 & 5 & & & & 1 & & 1 & 4 & 80 \\
\hline
\end{tabular}

\section{Discussion}

Generally, the isopods parasitize many fishes' species worldwide causing significant economic losses (Ravichandran et al, 2011). They have been identified to cause deleterious effects on cultured fish, such as stunted growth, anemia, and mortalities of fries and fingerlings (Ravi and Rajkumar, 2007; Rameshkumar et al, 2013).

In the present study, Livoneca redmanii infested Solea solea was $20.30 \%$ in Lake Qarun. The percentage was higher than that 
recorded in Egypt for isopod infestation was 9\% from Mediterranean Sea at Port-Said and Matroh Governorates respectively (Abd El Aal and El Ashrum, 2011) and 10.26\% (Samn et al, 2014) from Mediterranean Sea at Alexandria Governorate. Also, it was higher than $(19 \%)$ reported by Eissa et al (2012) among Mediterranean Sea fishes and lower than that recorded from Suez Canal in Ismailia province (24.4\%). Mahmoud et al (2016) in Lake Qarun revealed total prevalence of $32.66 \%$ with isopod infestation among $\mathrm{Di}$ centrarchus Labrax, Solea vulgaris and Tilapia zilli from Lake Qarun. These variations might be attributed to differences in the study times, climatic conditions, fish species and the geographical distribution of fish hosts and parasites.

Cymothoid isopods generally have a bimodal life cycle, in February and August (Aneesh et al, 2013). Female parasites with eggs were reported in February and August in the present study. The highest intensity and variety of parasites were detected in summer, whereas the lowest were in winter. These parasites usually prefer the coastal area, while fish migrate to deeper waters in the winter season due to changes of water temperatures (Er and Kayis, 2015).

In the present study, the highest infestation of $L$. redmanii $(38.60 \%)$ on $S$. solea was in June and the lowest in October $(10.30 \%)$. This result agreed with El-Seify et al (2011) who reported that the highest seasonal prevalence of crustaceans among Oreochromis niloticus was in summer, then spring followed by autumn and finally in winter. Eissa et al (2012) recorded the summer showed the highest infestation (19\%), followed by autumn (17\%), then spring (7\%) and the lowest was $(4 \%)$ in winter. Noor El-Deen et al (2013) found that the highest infestation percentage of Nerocila orbignyi in European seabass was recorded during summer and spring seasons, while infestation was disappeared during autumn and winter seasons. Samn et al (2014) mentioned that the highest infestation percentage of Nerocila bivittata was recorded in summer $(10.26 \%)$ and the lowest $(2.70 \%)$ was in spring. Abdel-Latif (2016) found that the greatest occurrence of Nerocila was in summer, followed by winter. Mahmoud et al (2017) in Lake Qarun recorded the highest infestation rate in the summer $(73 \%)$, while the lowest was in winter $(28 \%)$.

In the present study, concerning sex, the infestation percentages of $L$. redmanii were increased in females $(23.50 \%)$ than males $(17.90 \%)$ in S. solea. It may be due to slow movement of females too easy to be infested by parasites. Samn et al (2014) noticed that Nerocila bivittata infest mostly females of Lithognathus mormyrus from Abu Qir Bay, Alexandria, Egypt.

In the present study, concerning with length groups, the highest infestation rate of $L$. redmanii on $S$. solea was recorded in medium size towards the large size fish. Concerning with the weight groups, the highest infestation rate was recorded in small weight towards the medium weight of fish. The relation between fish body weights, lengths and infestation rate was significant for infested fish. These findings agreed with Eissa et al (2012). They concluded that the infestation rate was increased with increasing in length and weight of infested fish. The lowest infestation occurred in large fish, which might be due to $S$. solea buried in the sediment during day time and become more active at night (Bishai and Kirollus, 1987).

Crustacean ecto-parasites on marine fish are diverse. Many species of fish are infested by cymothoids. They are blood-feeding; several species settle in the buccal cavity of fish, others live in the gill chamber or on the body surface including the fins. Their life cycle involves only one host (Holoxenic cycle) (Ramdane et al, 2007). In the present study, the ecto-parasitic isopods, L. redmanii infest gills, ventral side, dorsal side, mouth, head and tail sites on the integument of $S$. solea.

The position of attachment in ventral, dorsal, and tail sites might depend on the host's 
body movement. Fish swimming is undulatory movements of their body and/or their paired and unpaired fins. In undulatory swimming, a backward travelling wave is gene-percentage by the sequential activation of the segmental myotomes from head to tail (Altringham and Ellerby, 1999; Samn et al, 2014). The cause of attachment at this position may be due to easier attachment at this site by the parasite or due to easier shedding of the parasite from other areas by the host (Printrakoon and Purivirojkul, 2011).

Examination of the infested fish revealed that the intensity of infestation in $S$. solea was one or two per hosted fish in gills region or attached on the skin and slight protrusion of gill cover (operculum), atrophy and hemorrhage at site of attachment. These may be attributed to the low respired oxygen of destructed gill epithelium which caused by feeding activity, attachment, fixation and locomotion of crustaceans. These results agreed with Eissa et al (2012) in Suez Canal at Ismailia, and with Kayiş and Ceylan (2011) in Pazar coast, Black Sea, Turkey. They found a female Nerocila orbignyi between the operculum and pectoral fin of $S$. solea.

In the present study, the clinical examination of most infested fish, $S$. solea with $L$. redmanii showed some slight abnormalities as represented as respiratory manifestation, sluggish movement, some aggregated on the surface and accumulated at the mouth of agriculture drains and fresh water inlet of the pond. Also, fishes showed emaciation, excessive amounts of mucous covering the body surface and some fishes have scale sloughing. These results agreed with Noor ElDeen et al. (2013) at Kafr El Sheikh Governorate fish farms and Abdel-Mawla et al (2015) at Red Sea at Suez Canal. Excessive mucous secretion is used to dilute the irritation and act as a defense mechanism against infestation (Yambot and Lopez, 1997).

In the present study, postmortem showed that most infested $S$. solea with $L$. redmanii with mucus producing cells, ulcer and ero- sion in the gills. Their skin developed ulcers, scale less and discoloration. These results agreed with Eissa (2004) and Noor El-Deen et al. (2013).

In the present study, the gills of S. solea were highly infested $(73.7 \%)$ with $L$. redmanii, which consume on gill tissues. This result agreed with Manera and Dezfuli (2003). Adult isopods are hematophagus causing anemia (Ravi and Rajkumar, 2007). Consequently, the respiratory surface were seriously reduced by gills atrophy (Horton and Okamura, 2001; Mladineo, 2003; Toksen et al, 2008; Kayiş and Ceylan, 2011). Like most isopods, cymothoids feeds on the host blood, but also consume the mucus, epithelium and subcutaneous tissues (Ramdane et $a l, 2007)$. This fact was reported in the present study.

Mahmoud et al (2017) reported that treatment of crustacean parasites especially isopods was a complicated process and chemical agents is illogical and difficult to use with huge infestation in large water basin as in Lake Qarun.

\section{Conclusion}

No doubt, fish contribute much as one of the main sources of protein for human consumption. The outcome results showed fresh water considered the best and effective to eliminate the cymothoid isopod, L. redmanii infest fish in Qarun Lake. This is no practical. So, to find out a biological means to control this pest and to safe fish is more feasible.

\section{Recommendations}

1. Reduction of the lake salinity, since the low salinity water kill $L$. redmanii. The effectiveness of the fresh water might be due to osmotic concentration. The parasites numbers in the Lake eastern region (low salinity) was lower than in western region (high salinity); infested fish aggregated on the water surface and accumulated at the agricultural mouths drains with fresh water to get rid of them.

2. Cymothoid isopod, L. redmanii is holoxenic, and dies with its host death. This might 
by achieved by stopping adding of any fries of the hosted fishes on the long run. Then after, the lake could be re-aquaculture by the non-infested fry and fingerling of fishes.

\section{References}

Abd El Aal, AMI, El Ashram, AMM, 2011: A morphological study (SEM) on a parasitic marine isopod, Cymothoa spinipalpa (Isopoda: Cymothoidae). Egypt. J. Aquacu. 1:17-26.

Abdel-Latif, HMR, 2016: Cymothoid parasite, Nerocila Orbigni inflicts great losses on Tilapia Zilli in Lake Qarun at El-Fayoum Governorate. Int. J. Innovative Stud. Aquacu. Biol. Fisher. 2, 3:1-9.

Abdel-Mawla, HI, El-Lamie, MMM, Dessouki, AA, 2015: Investigation on ectoparasitic crustacean diseases in some Red Sea fishes and their associated pathological lesions. Benha Vet. Med. J. 28, 1:301-9.

Altringham, JD, Ellerby, DJ, 1999: Fish swimming: Patterns in muscle function. J. Exp. Biol. 202:3397-403.

Aneesh, PT, Sudha, K, Arshad, K, Anilkumar, G, Trilles, JP 2013: Seasonal fluctuation of the prevalence of cymothoids representing the genus Nerocila (Crustacea, Isopoda), parasitizing commercially exploited marine fishes from the Malabar Coast, India. Acta Parasitol. 58:8090.

Azab, AM, Khalaf-Allah, HMM, Afifi, MAM, 2015: Reproductive biology of males pipefish, Trachyramphus bicoarctatus (Teleostei: Syngnathidae) at Lake Qarun, Egypt. Int. J. Develop. 4, 1:61-75.

Bishai, HM, Kirollus, SY, 1987: Seasonal abundance and distribution of larvae and early stages of sole, Solea vulgaris Quensel in Lake Qarun. Proc. Zool. Soc. A.R Egypt. 14:179-87.

Brusca, RC, 1981: A monograph on the Isopoda Cymothoidae (Crustacea) of the Eastern Pacific. Zool. J. Linn. Soc. 73, 2:117-99.

Cuyas, C, Castro, JJ, Ortega, SAT, CarboneIl, E, 2004: Insult stock identification of Serranus atricauda (Pisces: Serranidae) through the presence of Ceratothoastein dachneri (Isopoda: Cymothoidae) and Pentacapsu lacutanea (Myoxoa: Pentacapsulidae) in the Canary Islands. Sci. Mar. 68:159-63.

Eissa, IAM, 2004: The Parasitic Fish Diseases in Egypt. $2^{\text {nd }}$ edition: Dar El-Nahda, El-Arabia Publishing, Cairo, Egypt.

Eissa, IAM, El-Lamie, M, Zakai, M, 2012: Studies on crustacean diseases of seabass, Morone
Labrax, in Suez Canal, Ismailia Governorate. Life Sci. J. 9, 3:512-8.

El-Seify, MA, Zaki, MS, Desouk, AY, Abbas, HH, Abdel Hady, OA, Abou Zaid, AA, 2011: Seasonal variations and prevalence of some external parasites affecting freshwater fishes reared at Upper Egypt. Life Sci. J. 8, 3: 397-400.

Er, A, Kayis, S, 2015: Intensity and prevale-nce of some crustacean fish parasites in Turkey and their molecular identification. Turk. J. Zool. 39: 1142-50.

Grutter, AS, 2003: Feeding ecology of the fish ectoparasite, Gnathia sp. (Crustacea: Isopoda), from the Great Barrier Reef, Australia and its implications for fish cleaning behavior. Mari. Ecol. Progr. Ser. 259:295-302.

Horton, T, Okamura, B, 2001: Cymothoid isopod parasites in aquaculture: a review and case study of a Turkish sea bass (Dicentrar chuslabrax) and sea bream (Sparusauratus) farm. Dis. Aqua. Organ. 46:181-8.

Kabata, Z, 1984: Diseases caused by metazoans: crustaceans. In: Diseases of Marine Animals. Kinne, O. (ed.). Hamburg, Germany: Biologische Anstalt Helgoland.

Kayiş, A, Ceylan, Y, 2011: First report of $\mathrm{Ne}$ rocila orbigyni (Crustacea, Isopoda, Cymothoidae) on Solea solea (Teleostei, Soleidae) from Turkish Sea. Turk. J. Fisher. Aqua. Sci. 11:1679.

Khalaf-Allah, HMM, 2014: Seasonal distribution and abundance of small fish in the South coast of Lake Qarun, Egypt. Wld. J. Fish Mari. Sci. 6, 1:109-18.

Mahmoud, NE, Fahmy, MM, Abuowarda, M M, 2017: An investigation of cymothoid isopod invasion in Lake Qarun Fishes with preliminary trial for biological control. Int. J. Chem. Tech. Res. 10, 2:409-16.

Mahmoud, NE, Fahmy, MM, Abuowarda, M M, Khattab, M, 2016: Parasitic cymothoid isopods and their impacts in commercially important fishes from Lake Qarun, Egypt. Int. J. Chem. Tech. Res. 9. 12:221-9.

Manera, M, Dezfuli, BS, 2003: Lernanthropus kroyeri infestations in farmed sea bass, Dicentrarchus labrax: Pathological features. Dis. Aquat. Organ. 57, 1/2:177-80.

Mladineo, I, 2003: Life cycle of Ceratothoa oestroides, a cymothoid isopod parasite from seabass, Dicentrarchus labrax and sea bream, Sparus aurata. Dis. Aqua. Organ. 57, 1/2:97-101. 
Noor El-Deen, AIE, Abdel Hady, OK, Shalaby, SI, Zaki, SN, 2012: Field Studies on Caligus disease among cultured (Mugil Cephalus) in brackish water fish farms. Life Sci. J. 9, 3:733-7.

Noor El-Deen, AE, Zaki, MS, Shalaby, IS, 2013: Some investigations observed in culture seabass (Dicentrarchus labrax L.) infested with Lernanthropus kroyeri and Nerocila orbignyi and exposed to pollution during different seasons at Damietta Governorate. Life Sci. J. 10, 3: 1877-84.

Printrakoon, C, Purivirojkul, V, 2011: Prevalence of Nerocila depressa (Isopoda, Cymothoidae) on Sardinella albella from a Thai Estuary. J. Sea Res. 65:322-6.

Ramdane, Z, Bensouilah, MA, Trilles, JP, 2007: The Cymothoidae (Crustacea, Isopoda), parasites on marine fishes from Algerian Fauna. Belg. J. Zool. 137, 1:67-74.

Rameshkumar, G, Ravichandran, S, Ahmad, AS, 2013: Study of functional morphology of mouthparts of parasitic isopods of marine fish's. Asi. Pac. J. Trop. Dis. 3, 2:127-32.

Ravi, V, Rajkumar, M, 2007: Effect of isopod parasite, Cymothoa indica on gobiid fish, Oxyurichthys microlepis from Parangipettai coastal waters (south-east coast of India). J. Environ. Biol. 28, 2:251-6.

Ravichandran, S, Rameshkumar, G, Trilles, JP, 2011: New records of two parasitic cy- mothoids from Indian fishes. J. Parasitol. Dis. 35, 2:232-4.

Saeed, SM, Shaker, IM, 2008: Assessment of heavy metal pollution in water and sediments and their effect on Oreochromis niloticus in the Northern Delta lakes, Egypt. Int. Symp. Tilapia in Aquacu. 4:75-89.

Samn, AA, Metwally, KM, Zeina, AF, Khalaf -Allah, HMM, 2014: First occurrence of Nerocila bivittata: parasitic Isopods (skin shedders) on Lithognathus mormyrus (Osteichthyes, Sparidae) from Abu Qir Bay, Alexandria, Egypt. J. Amer. Sci. 10, 7:171-9.

Toksen, E, Nemli, E, Degirmenci, U, 2008: The morphology of Lernanthropus kroyeri Van Beneden, 1851 (Copepoda: Lernanthropidae) parasitic on seabass, Dicentrarchus labrax (L., 1758), from the Aegean Sea, Turkey, Acta Parasitol. Turcica 32, 4:386-9.

Woo, PTK, 2006: Fish Diseases and Disorders, Vol. 1: Protozoan and Metazoan infestations. $2^{\text {nd }}$ Edition: Library of Congress Cataloging in-Publication Data.

Yambot, AV, Lopez, EA, 1997: Gill parasite, Lamproglena monody, Capart, infecting the Nile tilapia, Oreochromis niloticus L., cultured in Philippines. In: Diseases in Asian Aquaculture III. Flagel, TW \& Raeeds, IHM (eds.). Asian Fishing Society, Manila.

\section{Explanation of figures}

Fig. 1: Map of Lake Qarun showing study area, $0---1 \mathrm{Cm}=5 \mathrm{Km}$. Fig. 2: Livoneca redmanii A, male dorsal view; B, male ventral view; C, female dorsal view and $\mathrm{D}$, female ventral view

Fig. 7: S. solea infested gills, Fig. 8: S. solea infested skin. Fig.10: S. solea infested gill region extended to operculum, Fig. 11: Infested S. solea emaciation with mucous covering its body, Fig. 12: S. solea with infested gill, poster part of one protruded outside, Fig. 13: Infested $S$. solea with focal erosion on gills and skin.
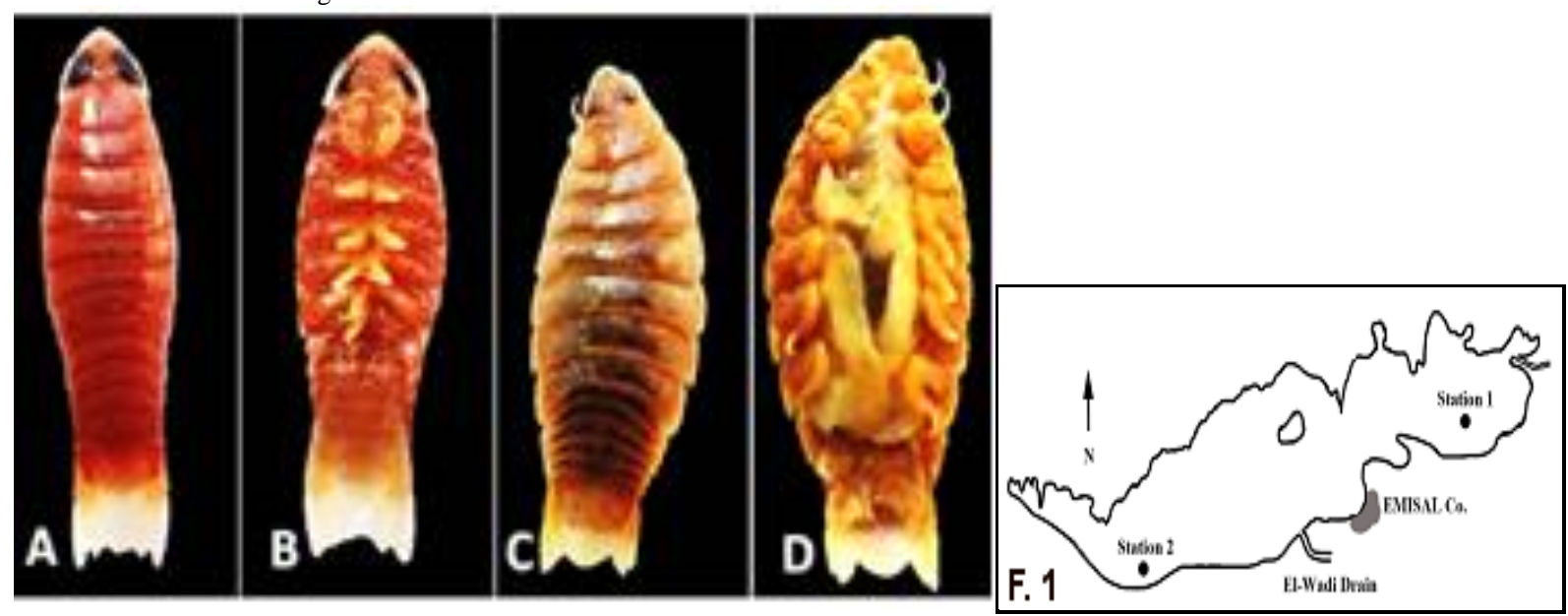


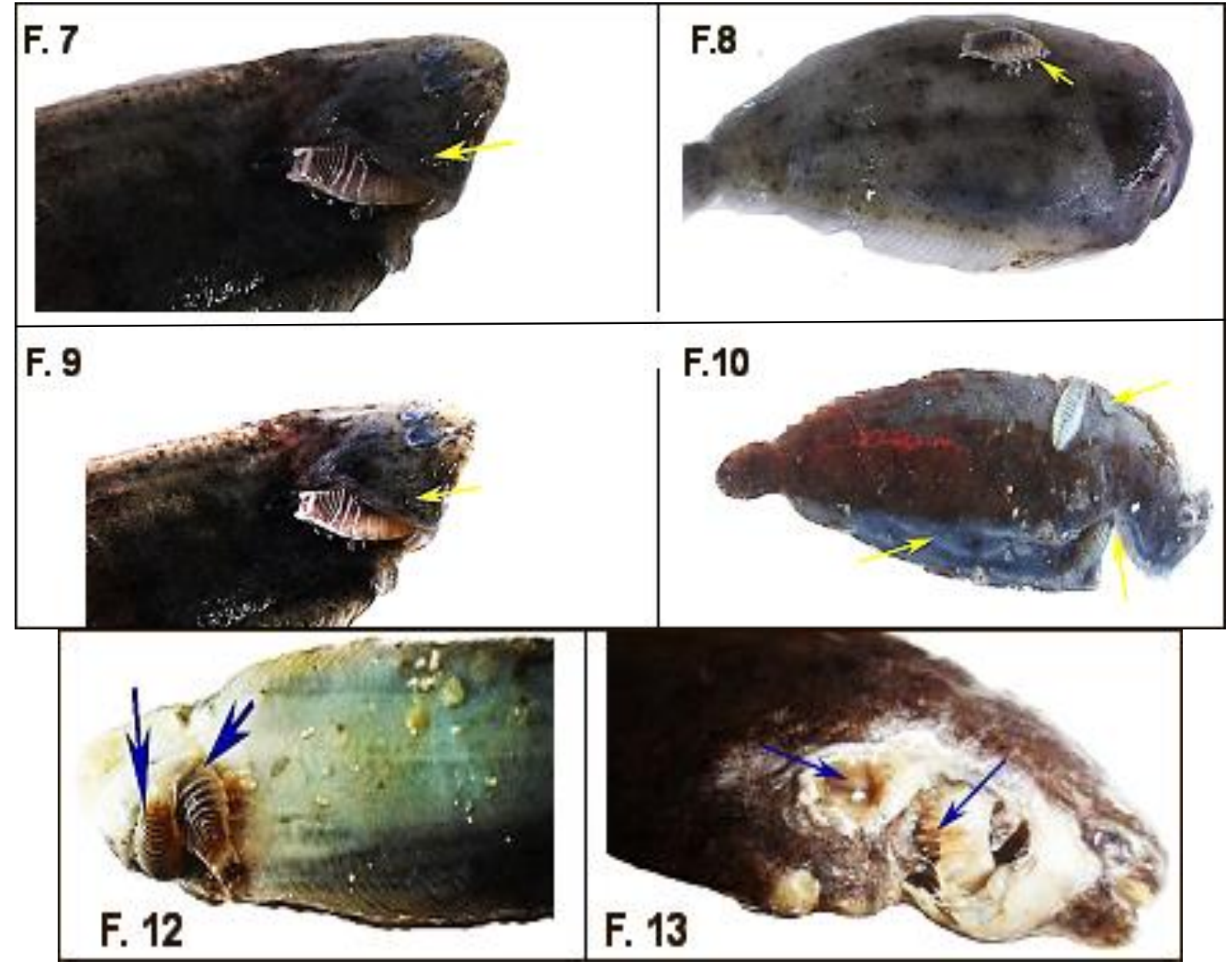

